\title{
A Remedy for the Victims of Pollution Permit Markets
}

The current federal scheme for controlling air pollution involves a comprehensive regulatory program that imposes uniform, site-specific emission limitations. Economists have criticized this system as severely inefficient and have offered a number of alternatives, including the use of marketable pollution permits.

This Note points out that pollution markets can produce high localized pollution concentrations, thereby creating severe inequities for a few citizens. Because present common-law remedies may be inadequate to compensate these victims and because compensation by an individual polluter does not equitably involve all of the parties benefiting from a localized "hot spot," this Note argues that the government should compensate victims. Takings doctrine provides support for the view that the government has "taken" property when it adopts a market approach resulting in hot spots. Furthermore, takings analysis provides the basis for a statutory cause of action against the government to remedy the injuries caused by the market. The Note concludes that such a statute, embodying precise standards of liability and creating an administrative tribunal to hear claims, should be adopted at the federal level. ${ }^{\mathbf{1}}$

\section{The Clean Air Act and National Ambient Air Quality Standards}

The 1970 amendments to the Clean Air Act ${ }^{2}$ enacted a comprehensive scheme for regulating emissions from industrial facilities. The National Ambient Air Quality Standards (NAAQS) 3 form the centerpiece of the program. Congress authorized the Administrator of the Environmental Protection Agency (EPA) to establish primary and secondary NAAQS, setting ceiling ambient concentrations for each pollutant for which the Administrator has issued "air quality criteria." The primary standard must

1. Lying behind this Note is the broader question whether Congress should create a market at all. This Note does not address that problem directly, preferring instead to provide a remedial framework in case Congress does act. Any debate over the issue would invoke the ideals of equity on the one hand and efficiency on the other. This Note assumes the establishment of a market in pollution permits and seeks to incorporate the ideals of both efficiency and equity.

2. Pub. L. No. 91-604, 84 Stat. 1676 (1970) (codified as amended at 42 U.S.C. $\$ \S 7401-7642$ (Supp. V 1981)).

3. 42 U.S.C. $\$ 7409$ (Supp. V 1981).

4. Id. $\$ 7409$ (a)(1)(A). EPA has issued criteria documents for sulfur dioxide, carbon monoxide, nitrogen dioxide, particulates, ozone, hydrocarbons, and lead. R. LIROFF, AIR POLLUTION OFFSETS 3 , 45 n.3 (1980). 
protect health; ${ }^{\sigma}$ the secondary standard must protect public welfare. ${ }^{6}$ Once NAAQS are adopted, the states are required to develop comprehensive State Implementation Plans (SIPs), including site-specific emission limitations, ${ }^{7}$ to ensure compliance with the ambient standards within each Air Quality Control Region (AQGR). ${ }^{8}$

Congress intended the NAAQS to be geographically uniform, applicable in every part of each state, ${ }^{9}$ and the EPA has required compliance at every measurement site within a region. ${ }^{10}$ This strict adherence to uniformity reflects an equitable principle in the Act-the desire to "protect the health of persons" regardless of their location, wealth, or susceptibility to disease. ${ }^{11}$

5. 42 U.S.C. $\$ 7409$ (b)(1) (Supp. V 1981). The primary standard for each "criteria" pollutant must specify the ceiling on permissible concentration "requisite to protect the public health" and "allowing an adequate margin of safety." Id.

6. Id. $\S 7409(\mathrm{~b})(2)$. The secondary standard must limit concentration to the level necessary "to protect the public welfare from any known or anticipated adverse effects . . . ." Id. Adverse effects on welfare include damage to soil, water, vegetation, man-made materials, wildlife, visibility, climate, and economic values. See S. REP. No. 1196, 91st Cong., 2d Sess. 11 (1970); A. KNEESE \& C. SCHULTZE, POLLUTION, PRICES, AND PUBLIC POLICY 52 (1975); Krier, The Irrational National Air Quality Standards: Macro- and Micro-Mistakes, 22 U.C.L.A. L. REV. 323, 325 (1974).

7. The standards for new sources must incorporate specific federal requirements. See 42 U.S.C. § 7411 (Supp. V 1981) (establishing new source performance standards). The state itself may set requirements for old sources. In both cases, however, the SIP requirements must ensure compliance with NAAQS.

8. Id. $\S 7410(\mathrm{a})$. The states must achieve primary standards within three years of promulgation and must achieve secondary standards within a "reasonable time." Id. $\S 7410(\mathrm{a})(2)(\mathrm{A})$. The Administrator may grant a two-year extension of the deadline for attainment of primary standards if the original deadline is impractical. Id. $\$ 7410(\mathrm{e})(1)$. In any event, however, the Act required attainment of primary NAAQS by 1977. R. STEWART \& J. KRIER, ENVIRONMENTAL LAW AND POLICY 342 (2d ed. 1978).

9. See 42 U.S.C. $\$ \S 7407(a), 7410(a)(1)$ (Supp. V 1981); R. STEWART \& J. KRIER, supra note 8, at 341,364 ; Krier, supra note 6 , at $324-25$.

10. See 40 C.F.R. $\$ 50$ (1983); see also United States Steel Corp. v. EPA, 605 F.2d 283, 291-94 (7th Cir. 1979) (non-attainment designation because NAAQS exceeded at one monitoring site), cert. denied, 444 U.S. 1035 (1980). The EPA has proposed that measurement sites be located close to one another in the vicinity of an emission source. See OFFICE OF AIR QUALITY PLANNING AND STANDARD RESEARCH, GUIDELINES ON AIR QUALITY MODELS: PROPOSED REVISION 37-38 (1980). Such tight clusters of receptors help to ensure compliance with ambient standards in the areas immediately surrounding emission sources.

11. See S. REP. NO. 1196 , supra note 6, at 10 ("In requiring that national ambient air quality standards be established at a level necessary to protect the health of persons, . . . the Committee emphasizes that included among those persons . . . are particularly sensitive citizens such as bronchial asthmatics and emphysematics who in the normal course of daily activity are exposed to the ambient environment."); Krier, supra note 6, at 329.

In line with the commitment to uniform health, technological infeasibility and high cost would not be considered in setting NAAQS and would not justify a polluter's failure to meet the standards. See Lead Indus. Ass'n v. EPA, 647 F.2d 1130, $1148-49$ (D.C. Cir.), cert. denied, 449 U.S. 1042 (1980); S. REP. No. 1196, supra note 6 , at 2,3 (1970).

A second principle informing the Act is the congressional intent to involve the public in all phases of the regulatory process. The Senate Public Works Committee Report called the committee's concern to preserve public participation a "unique feature of the Air Quality Act of 1967." S. REP. NO. 1196, supra note 6, at 3; see also Hearings on S. 3229, S. 3466, S. 3546 Before the Subcomm. on Air and Water Pollution of the Senate Comm. on Public Works, 91st Cong., 2d Sess. 620, 621 (1970) (statement of Rep. Mikva) (standard-setting requires public policy decisions in which citizens should be 


\section{Market Alternatives to Uniform Controls}

Several economists, however, have criticized the inefficiency of uniform controls. ${ }^{12}$ The costs to polluters of achieving a given pollution level and, conversely, the costs to society if that level is exceeded, will vary greatly among regions. ${ }^{18}$ Moreover, the marginal costs of controlling emissions will vary among different industrial plants. ${ }^{14}$ Thus, a uniform standard is likely to result in an inefficient allocation of pollution controls. In addition, prescriptive regulations offer no incentives for reduction of emissions below the level mandated by NAAQS. ${ }^{15}$

Many theorists have suggested pricing mechanisms to overcome the inefficiencies of prescriptive regulation. ${ }^{16}$ The proposals include governmental subsidies for pollution reduction, ${ }^{17}$ "effluent charges"18 (levies on each increment of pollution), and markets in pollution rights. ${ }^{18}$ Marketable

involved) [hereinafter cited as Hearings]. The 1970 Act provides for written comments at the standard-setting stage and public hearings at the implementation stage. 42 U.S.C. $\S \S 7409(a)(1)(B)$, 7410(a)(1) (Supp. V 1981).

12. See, e.g., B. AcKerman, S. Rose-AcKerman, J. SAWYer \& D. Henderson, The UncerTAIN SEARCH FOR ENVIRONMENTAL QUALITY 228-29 (1974) (uniform controls fail to "discriminate between high- and low-cost treatment possibilities") [hereinafter cited as UNCERTAIN SEARCH]; $W$. BAUMOL \& W. OATES, ECONOMICS, ENVIRONMENTAL POLICY, AND THE QUALTTY OF LIFE 238 (1979) (pollution control more costly under uniform standards than under other systems); W. BAXTER, PEOPLE OR PENGUINS: THE CASE FOR OPTIMAL POLlUTTON 63-68 (1974) (same); Krier, supra note 6, at 324-30 (NAAQS fail to take account of regional differences); Zerbe, Optimal Environmental Jurisdictions, 4 ECOLOGY L.Q. 193, 212-13, 215-16 (1974) (uniform controls contrast with diversity in society).

13. The costs of achieving a given standard will depend on initial pollution levels, population, geographical features, and atmospheric conditions. The costs to society of greater air pollution (including aesthetic and health costs) will differ, depending on the uses of land and the attitudes of people in different areas. See Krier, supra note 6, at 327; cf. J. DAles, POLLUTION, PROPERTY AND PRICES 50, 51-52 (1968) (varying costs of given levels of pollution).

14. See W. BAUMOL \& W. OATES, supra note 12, at 338-40; del Calvo y Gonzalez, Markets in Air: Problems and Prospects of Controlled Trading, 5 HARV. ENVTL. L. REV. 377, 386 (1981); Tietenberg, The Design of Property Rights of Air-Pollution Control, 22 PUB. POL'Y 275, 279 (1974).

15. See W. BaUMOL \& W. OATES, supra note 12 , at 236-37.

16. See UNCERTAIN SEARCH, supra note 12 , at $260-81$; J. DALES, supra note 13 , at $88-97$. The EPA could overcome the inefficiencies of prescriptive regulation by setting pollution controls at the optimal level, given the marginal abatement costs of each polluter and the available alternatives. Such an efficient prescription of controls, however, would require a huge body of accurate information. The administrative costs of acquiring that information would be astronomical, and the chance of error and the cost of such error would be high.

17. Cf. A. KNEESE \& C. SCHULTZE, supra note 6, a\& 34-38 (recognizing weaknesses in subsidy approach); J. DALES, supra note 13, at 81 (same). Subsidies tend to be linked to the use of particular control technologies, thereby limiting flexibility. See A. KNEESE \& C. SCHULTZE, supra note 6, at 37 . In addition, the government must have sufficient information to match subsidy payments to the marginal cost of reductions. The information costs could again be very high. See J. DALES, supra note 13, at 87.

18. See W. BAUMOL \& W. OATES, supra note 12, at 246-50, 255-67; A. KNEESE \& B. BOWER, MANAGING WATER QUALITY: ECONOMICS, TECHNOLOGY, INSTITUTIONS 97-101, 131-72 (1973). But see Rose-Ackerman, Effuent Charges: A Critique, 6 CANADIAN J. ECON. 512 (1973) (enumerating potential inefficiencies in effluent charge scheme).

19. UNCERTAIN SEARCH, supra note 12, at 260-81; W. BAUMOL \& W. OATES, supra note 12 , at 250-53; J. DALES, supra note 13, at 93-97; Hahn \& Noll, Designing a Market for Tradable Emissions Permits, in REFORM OF ENVIRONMENTAL REGULATION 119, 120-23 (W. Magat ed. 1982). 
rights offer several advantages over subsidies and effluent charges; ${ }^{20}$ in addition, recent changes in federal policy indicate a willingness to experiment with markets in emission rights. ${ }^{21}$

The structure of a pollution market is fairly simple. ${ }^{22}$ At the outset, the government would define a market region and determine the overall level of emissions for each pollutant within that region. It would then distribute a limited number of permits for each pollutant, ${ }^{23}$ each permit representing

20. See supra note 17 (relative disadvantages of subsidies). Baumol and Oates note that permit markets are superior to effluent charges, because markets (1) are invulnerable to inflation, (2) are invulnerable to increases in population and industrial activity, (3) allow different numbers of permits in different geographical regions, and (4) insure a certain level of emissions. W. BAUMOL \& W. OATES, supra note 12, at 251-52. Permit markets avoid the danger of excess pollution that result if effluent charges are set too low. See UNCERTAIN SEARCH, supra note 12, at 262-67.

21. Congress and the EPA have begun to experiment with limited markets, permitting the trading of "emission offsets" in areas that have not yet attained NAAQS. See Air Quality Standards Interpretative Ruling, 41 Fed. Reg. 55,524 (1976), revised at 44 Fed. Reg. 3274 (1979) (codified at 40 C.F.R. $\S 51$, app. S (1983)) (hereinafter cited as EPA Ruling]; 42 U.S.C. §§ 7501-7503 (Supp. V 1981). Responding to a concern that major new stationary sources or major modification of existing sources would not be permitted in non-attainment areas, EPA announced that it would allow new construction or modification only if the overall level of emissions in the AQCR were decreased. See EPA Ruling, supra, 41 Fed. Reg. at 55,529; Rosenberg \& Friedman, Air Quality and Industrial Growth: The Location of New Industrial Sources of Pollution in Non-Attainment Areas, 11 NAT. RESOURCES LAW. 523, 534-35 (1978); Note, Emission-Offset Banking: Accommodating Industrial Growth with Air Quality Standards, 128 U. PA. L. REV. 937, 940-41 (1980). In other words, new sources must obtain offsetting decreases in emissions from existing sources in the area, and the decreases must more than offset anticipated emissions by the new facility. 40 C.F.R. $\S 50$ app. S, IV (A), condition 4 (1983) ("The emission offsets will provide a positive net air quality benefit in the affected area....").

The EPA policy made it possible for a new firm to purchase "offsets" from existing firms. See R. LIROFF, supra note 4, at 17-19, 33; Note, supra, at 937. Moreover, in 1979, EPA allowed existing plants to reduce emissions unilaterally and bank those offsets until a buyer could be found in the future. See 44 Fed. Reg. 3274, 3280 (1979); Comment, Who Owns the Air? The Emission Offset Concept and Its Implications, 9 ENVTL. L. 575, 594-95 (1979).

However, to date there are only three regional emissions banks, and, in general, the EPA approach imposes severe restrictions on trading. The new source must meet the "lowest achievable emission rate"; the applicant must certify that all existing major sources owned by the applicant in the AQCR are in compliance with SIP limitations; the trade must achieve "reasonable progress" toward attainment of NAAQS; and the offsets must provide a net air quality benefit in the affected area. 40 C.F.R. $\S 50$, App. S, IV (A) (1983). For these and other reasons, an active market has not developed under the EPA regulations. See del Calvo y Gonzalez, supra note 14, at 401.

In 1977, Congress enacted the substance of the "emission offset" policy in the non-attainment provisions of the Clean Air Act. 42 U.S.C. $\$ \S 7501-7503$ (Supp. V 1981). The only significant departure from the EPA approach is the absence of an explicit requirement that there be a "net air quality benefit" in the immediate vicinity. The non-attainment provisions merely require reasonable further progress towards the attainment of NAAQS. Id. $\S 7503$.

Two bills introduced in Congress in 1983, S. 145, 98th Cong., 1st Sess. (1983), and H.R. 132, 98th Cong., 1st Sess. (1983), would employ emission offsets as tools to control the interstate transport of sulfur oxides.

22. Cf. W. BAUMOL \& W. OATES, supra note 12, at 251-53 (giving general description of water pollution market); J. DALES, supra note 13, at 93-98 (same).

23. The government could distribute permits in one of several ways. For example, it could hold an auction, selling permits to the highest bidders. See, e.g., UNCERTAIN SEARCH, supra note 12, at 272-73; J. DALES, supra note 13, at 93-94.

Alternatively, the government could distribute permits according to the old SIP requirements. If the overall level of emissions established for the market equaled those permitted by the SIP, the government could simply create permits granting each emitter the same level of pollution he was previously 
the right to emit a particular amount of pollution for a specific period of time. The sum of the permits for each pollutant would equal the total amount of emissions of the pollutant allowable within the market region. Polluters in the region would be allowed to buy or sell permits.

The market would allow polluters themselves to determine the most economical mix of pollution controls within a geographical region. Industries with relatively high marginal abatement costs would buy emission permits, until the marginal cost of abating one unit of pollution equalled the price of a permit. ${ }^{24}$ The price of permits would fluctuate with the market, ultimately reaching an equilibrium in which the marginal abatement cost of every firm was the same and equal to the price of a pollution right. Once in place, the market system would theoretically minimize the total cost to emitters of achieving a given level of air quality. ${ }^{25}$ Moreover, since a firm could sell any unused permits, it would have an incentive to develop and incorporate more effective methods of reducing emissions.

\section{The Hot Spot}

Although a market in pollution rights, once established, would represent an efficient system in terms of industry's marginal costs of control, such a market would result in localized concentrations of pollution above the average, pre-market level. If permits were issued for a pollutant that settled out close to its source, producing local effects, ${ }^{26}$ and if one or more

assigned. Even if overall emissions under the market were different from those under the SIP, the government could still look to the SIP requirements for guidance, for example, in distributing permits pro rata according to the former requirements.

Finally, the government could use other criteria (for example, the relative "importance" of different industries as judged by number of employees hired) to distribute permits on a case-by-case basis. Such an approach, however, would require complex and costly governmental fact-finding and decisionmaking.

24. See UNCERTAIN SEARCH, supra note 12, at 261. Alternatively, a polluter with low marginal abatement costs would reduce emissions and sell pollution rights until its abatement costs equaled the cost of a permit. A firm might even realize that no level of production would be as lucrative as the sale of its pollution rights and other assets.

25. Id. But see W. BAUMOL \& W. OATES, supra note 12, at 252-53 (arguing that although this distribution of controls is cost-effective for a given quantity of total emissions, that quantity may not be ideal because resources for cleaning the air are diverted from other important societal programs).

The efficiency of the market may also be impaired by high start-up and transaction costs. Implementing the new program would produce initial costs for both government and businesses. The government would have to develop a system for issuing permits and new enforcement mechanisms (able to keep track of the shifting patterns of permit ownership). Businesses would have to develop new control strategies (calculating the marginal costs of buying and selling permits) and new methods for marketing permits.

Even after the system was in place, transaction costs would lessen the efficiencies of the market. The government would have to oversee and record trades, and enforce the changing pollution requirements; and businessmen would have to continue to monitor the market and the availability of buyers and sellers.

26. See Note, Technology-Based Emission and Effluent Standards and the Achievement of Ambient Environmental Objectives, 91 YALE L.J. 792, 810 (1982) (discussing distinction between sitespecific "local" pollutants and long-range "global" pollutants). 
firms within a locality purchased a large number of permits, then local concentrations might far exceed the level prescribed by the former air quality standards. Such a situation would occur, for example, if a large emissions source had been required under a SIP to adopt abatement methods with higher marginal costs than other plants. ${ }^{27}$ Once a market developed, the firm would buy large numbers of pollution permits rather than pay the higher costs of abatement. ${ }^{28}$ If the firm's SIP restrictions had been tailored to allow the highest possible local concentrations without violating NAAQS, the purchase of additional permits would create concentrations in excess of NAAQS in the vicinity of the plant. ${ }^{20}$

The likelihood of such a geographical "hot-spot" increases with the size of the market region; ${ }^{30}$ larger regions will contain more potential emission traders and greater disparity between marginal costs. In addition, a larger market region increases the likelihood that the seller and buyer of pollution rights are not in the same immediate vicinity and that emission reductions by the seller do not cancel out emission increases by the purchaser. ${ }^{31}$

The possibility of a hot spot reflects an inherent inequity in the market system, for a few citizens would suffer for the benefit of society as a whole. The overall market region would benefit from improved air quality $^{32}$ and lower control costs that would be reflected in consumer prices. ${ }^{33}$ Persons living near the hot-spot polluter, however, would be burdened by

27. See Hahn \& Noll, supra note 19 , at 129 (noting relatively high marginal costs of abatement for utilities under present policies).

28. Id.

29. Hot spots might likewise result if governmental regulations specifically designated certain high concentration regions. For example, if the government ostensibly relaxed NAAQS across the board but left strict limitations in the great majority of regions under the Prevention of Significant Deterioration (PSD) program, 42 U.S.C. $\$ \S 7470-7479$ (Supp. V 1981), then localized concentrations might occur in the non-PSD regions. The remedy for market hot spots proposed in this Note, see infra pp. $1032-40$, would apply equally well to hot spots resulting from non-uniform standards.

30. See Hahn \& Noll, supra note 19, at 122. Prevailing winds and geographical features (taken into account in the current regulatory scheme but ignored in a market that counts only total emissions) might also intensify concentrations. Moreover, trades to plants with lower smoke stacks would increase localized pollution levels.

31. California has already developed offset rules, see supra note 21, that may allow hot spots to develop. In fact, in 1979, the Bay Area Air Quality Management District (BAAQMD) in San Francisco authorized the Wickland Oil Company to obtain sulfur dioxide and hydrocarbon offsets from a dry cleaner and from sulfur-burning ships located at some distance from the Company's proposed new oil receiving facility. See R. LIROFF, supra note 4, at 33. Environmentalists claimed that the trade would worsen local pollution levels, already in excess of NAAQS. Id. at 33, 53 n.110. The Company agreed in an administrative settlement to alter the terms of the transaction. Nevertheless, the original proposal arguably met the requirements of BAAQMD regulations. The District has since altered its rules to set stricter limitations on the geograpical distance between buyers and sellers of offsets.

32. Regional air quality would improve because much of the market's pollution would be concentrated in a limited area. Site-specific pollutants would settle out near the plant, leaving cleaner air for the rest of the AQCR.

33. As a firm reduced its emission controls costs, the average costs of its products would decline. Assuming that the firm operated in a competitive market, these savings would be passed on to consumers. 
pollution levels above the former primary and secondary NAAQS. Such high concentrations would cause injuries to health, assuming that primary standards had been accurately based on health effects. ${ }^{34}$ The higher concentrations would also drive down property values, ${ }^{35}$ as smoke, odors, damage to improvements, and anticipated injuries to health interfered with current uses of the property and rendered the land less desirable. ${ }^{36}$

\section{A. Barriers to Market Participation}

Some economists have argued that the individual could purchase cleaner air by buying permits on the pollution permit market. ${ }^{37}$ Furthermore, groups of landowners could theoretically organize to purchase permits. In practice, however, this strategy is not likely to be effective. The cost of emission rights could be very high, ${ }^{38}$ and hot-spot victims might have to purchase a large number of permits to clean up a neighboring polluter, ${ }^{39}$ thus making the overall cost prohibitive. ${ }^{40}$ In addition, although economists foresee free entry into the market, local governments might facilitate $^{41}$ and even subsidize ${ }^{42}$ the purchase of pollution rights by new indus-

34. But cf. A. KNEESE \& C. SCHULTZE, supra note 6, at 51-52 (doubting whether there are threshold pollution levels below which health effects do not occur). The authors assume, however, that injuries to health do increase with pollution exposure. See id. at 16-17.

35. Environmental economists generally assume that, ceteris paribus, as pollution concentration increases, the value of property decreases. See A. KNEESE \& B. BOWER, supra note 18, at 136. Local zoning ordinances could mitigate somewhat the pollution-related diminutions in property values by ensuring that industrial plants are zoned away from other properties.

36. These injuries would be compounded, because the market would have been instituted in the wake of a prescriptive system that promised a minimum level of air quality everywhere. See supra p. 1023. The landowner's reliance on that minimum had been reflected in the price he paid for the property. A subsequent decline in value would injure him directly.

If he had bought property after the market had been instituted but while the pollution level in the vicinity met the former NAAQS, the price for the property would theoretically reflect the risk of a future hot spot and therefore would be somewhat-lower than under the NAAQS system. The great uncertainty about where hot spots would occur, however, would minimize this decline in value; and the subsequent development of a nearby hot spot would still lower property values and result in an injury not shared by most other citizens.

37. See J. DALES, supra note 13 , at $95-98$.

38. See Hahn \& Noll, supra note 19 , at 132.

39. See supra p. 1027.

40. Hot spots are likely to occur in areas of lower-income housing that are located near industrial zones. The market scheme thus would place inequitable burdens on lower-income residents, who could not compete in an emissions market.

41. For example, the California Air Resources Board facilitated “emissions offset" trades, see supra note 31 , to spur development. R. LIROFF, supra note 4 , at 17-18.

42. See, e.g., id. at 13-17 (Pennsylvania financed offsets as part of incentive package to induce Volkswagen Corp. to build plant within state); id. at 15-17 (Virginia provided free offsets to encourage construction of new oil refinery).

A government might provide such incentives in order to bolster the local economy. The smooth operation of the market permits industrial growth beyond that possible under command-and-control regulations. A firm can increase output without violating regulatory standards and at a lower cost than if it also had to prevent its emissions from increasing. Moreover, new and more efficient firms can enter a locality (which would not have had room for more polluters under NAAQS) by purchasing permits. 
tries, thereby weakening the ability of hot-spot victims to retire useful permits. ${ }^{43}$

\section{B. Insufficiency of Legal Remedies Against the Polluter}

Under the market scheme, hot-spot victims would not necessarily have a cause of action against the polluter. First, since there would be no violation of federal standards, the citizens' suit provisions of the Clean Air Act ${ }^{44}$ would not apply. In addition, common law actions might not be viable. In Milwaukee v. Illinois, ${ }^{45}$ the United States Supreme Court recently held that the Federal Water Pollution Control Act preempts federal common law nuisance actions. The Second Circuit noted, in New England Legal Foundation v. Costle, ${ }^{\text {t8 }}$ that the Supreme Court's logic might apply to the Clean Air Act as well.

Even if common law actions were not preempted, state and federal authorization of a hot spot would have a significant impact on decisions by local courts. A court may deny recovery for an intentional nuisance if the conduct is "reasonable." State and federal regulations authorizing the defendant's pollution level would have a strong bearing on the determination of reasonableness. ${ }^{48}$ Furthermore, in determining reasonableness, the

43. To the extent that landowners cannot participate in the market, they are denied a voice in the allocation process. A democratic legislature would presumably institute the market. But once the market was in place, allocations having great societal consequences would be made by an undemocratic institution representing only one concern: controlling emissions at the lowest cost.

44. 42 U.S.C. $\$ 7604$ (Supp. V 1981) (creating cause of action by citizen against polluter for violation of Clean Air Act).

45. 451 U.S. 304 (1981).

46. 666 F.2d 30 (2d Cir. 1981). The court in New England Legal Foundation dismissed a nuisance action on the ground that the EPA specifically authorized the defendant's use of high sulfur fuels. The court stated:

Congress has indicated that regulation may be better achieved through a comprehensive statutory approach than through ad hoc common law remedies. The federal courts of course must bow to that expression of congressional intent. To proceed otherwise by fashioning federal equitable remedies to proscribe the very conduct that the EPA, acting in its regulatory capacity pursuant to its statutory mandate, has specifically approved ... . would be both counterproductive and beyond the proper scope of the judicial function.

Id. at 33 (citations omitted); accord Connecticut v. Long Island Lighting Co., 535 F. Supp. 546, 551 (E.D.N.Y. 1982) (EPA approval of fuel sulfur content variance precluded nuisance suit).

47. See Mowrer v. Ashland Oil \& Ref. Co., 518 F.2d 659, 661 (7th Cir. 1975); Desruisseau v. Isley, 27 Ariz. App. 257, 260-61, 553 P.2d 1242, 1245-46 (1976); City of Chicago v. Commonwealth Edison Co., 24 IIl. App. 3d 624, 631-32, 321 N.E.2d 412, 418 (1974); RESTATEMENT (SECOND) OF TORTS § 826 (1979); see also Florida E. Coast Properties v. Metropolitan Dade County, 572 F.2d 1108,1112 (5th Cir.) (gravity of harm to plaintiff weighed against utility of defendant's conduct), cert. denied, 439 U.S. 894 (1978).

48. See City of Chicago v. Commonwealth Edison Co., 24 Ill. App. 3d 624, 632-33, 321 N.E.2d 412, 419 (1974) (federal pollution requirements influence court's reasonableness determination); see also Boccardo v. United States, 341 F. Supp. 858, 865 (N.D. Cal. 1972) (statutory requirements affect determination of reasonableness where " "legislature contemplated the doing of the very act which occasions the injury" ") (quoting Hassell v. City of San Francisco, 11 Cal. 2d 168, 171, 78 P.2d 1021, 1023 (1938)); Desruisseau v. Isley, 27 Ariz. App. 257, 261, 553 P.2d 1242, 1246 (1976) (compliance with zoning ordinance a "persuasive factor in determining the reasonableness of the activity"). 
court may weigh the burden to plaintiff against the utility of defendant's conduct. $^{49}$ In this case, benefits to society would include not only defendant's production but also the lower cost of pollution abatement and the research incentives created by the market. ${ }^{\text {so }}$

Practical barriers would also hinder nuisance suits. If several emission sources contributed to a localized concentration of pollution, a plaintiff might have difficulty in tying that condition to a particular defendant..1 Furthermore, the plaintiff might be unable to prove that the injury to health or property value resulted from air pollution. ${ }^{52}$ Finally, the operation of a market might pose devilish proximate cause problems: Did the firm that sold emission rights to defendant-polluter cause the plaintiff's injury? What about a governmental agency that encouraged and actively supported the trade?53 What about investment brokers and other participants in the market?

A final practical difficulty associated with both bringing suit and attempting to prevent hot spots by buying and retiring permits is the high cost of acting alone or organizing a class action. ${ }^{54}$ Under the current prescriptive air pollution control scheme, the government bears the cost of preventing high local concentrations by enforcing SIP limitations. ${ }^{\text {bS }}$ In a market system, the individual would have to bear the cost of abating local concentrations, either through market activity or litigation. Environmental

49. See Florida E. Coast Properties v. Metropolitan Dade County, 572 F.2d 1108, 1112 (5th Cir. 1978); Little Joseph Realty v. Town of Babylon, 41 N.Y.2d 738, 744-45, 363 N.E.2d 1163, 1168, 395 N.Y.S.2d 428, 433 (1977); Jewett v. Dearborn Enters., 281 Or. 469, 478-79, 575 P.2d 164, 169 (1978); RESTATEMENT (SECOND) OF TORTS § 826(a) (1979); Comment, The Environmental Lawsuit: Traditional Doctrines and Evolving Theories to Control Pollution, 16 WAYNE L. REV. 1085, 1110 (1970); Comment, State Air Pollution Control Legislation, 9 B.C. INDUS. \& COM. L. REV. 712, 717 (1968).

50. See supra pp. 1024-26.

51. See Comment, State Air Pollution Control Legislation, supra note 49, at 717; Hearings, supra note 11, at 836, 837-38 (statement of Bernard S. Cohen); see also Maas v. Perkins, 42 Wash. 2d 38, 43, 253 P.2d 427, 430 (1953) (requiring that injury be traceable to each defendant); O'Neal v. Southern Carbon Co., 216 La. 96, 101-02, 43 So. 2d 230, 232 (1949) (same). But see infra note 62 (methods of easing proof of causation).

52. See Hearings, supra note 11, at 836 (statement of James W. Jeans). Proving causation of injuries to health may be particularly difficult, for many diseases are believed to be the result of multiple causes. See, e.g., Industrial Union v. American Petroleum Inst., 448 U.S. 607, 633-34 (1980) (plurality opinion) (Benzene); Note, Tort Actions for Cancer: Deterrence, Compensation, and Environmental Carcinogenesis, 90 YALE L.J. 840, 848, 854 (1981). Furthermore, scientists are uncertain about what level of pollution is necessary to cause impairment to health. See Reserve Mining v. United States, 498 F.2d 1073, 1080 (8th Cir. 1974); McGarity, Substantive and Procedural Discretion in Administrative Resolution of Science Policy Questions: Regulating Carcinogens in EPA and OSHA, 67 GEO. L.J. 729, 736-47 (1979).

53. See supra p. 1028.

54. See Hearings, supra note 11, at 819 (statement of Stanley Preiser) (costs to litigants are "substantial deterrent" and will prevent most citizens from initiating litigation to abate nuisances).

55. This assumes that the government has the will and means to enforce regulations. The current Administration has reduced the enforcement activities of EPA. See [1981] 12 ENV'T REP. (BNA) 243. This move has slowed the government's response to violations of current standards. 
organizations might not support the plaintiff's claim, preferring instead the market that results in cleaner air in most areas and creates incentives for lower emissions and better control technology.

In sum, the difficulty of bringing suit, compounded by uncertainty over whether the common law action was preempted or weakened by equitable doctrines, would prevent many injured landowners from litigating their claims. The individual inequities created by the market system would go unremedied.

\section{Alternative Market Structures}

Congress could attempt to modify the market scheme in a way that would reduce the injury to individuals. For example, Congress might limit the size of the market region, with the expectation that emission decreases by sellers would offset increases by buyers. Such an approach, however, would restrict the number of potential sellers, stifling market activity. A seller must possess two characteristics: proximity to the buyer and lower marginal abatement costs. As participants in EPA's "emission offset" program have discovered, such a combination is rare. ${ }^{86}$ Even in an industrial zone, ${ }^{67}$ with numerous emitters, such trading would be scarce. In order to maintain clean air within the zone, each polluter would be required to reduce emissions to a very low level. Any additional reductions would be costly, making permits very expensive and chilling the market.

A second conceivable modification of the market structure would permit trading, but would retain a uniform ceiling on permissible concentrations (essentially a ceiling NAAQS). However, if the ceiling were set low enough to prevent hot spots, it would also restrict the number of pollution permits available to any single emitter. ${ }^{.8}$

A third alternative is to expand the market area by permitting exchanges between distant sources at uneven rates. The seller would decrease its emissions more than the buyer increased its levels, so that the seller's long-range effect on the buyer's vicinity would cancel out the hot spot. ${ }^{69}$ However, given geographical dispersion, the rates would have to be

56. See del Calvo y Gonzalez, supra note 14, at 401 n.147.

57. Many of the non-attainment areas qualifying for the "emission offset" program, see supra note 21, envelop industrial zones. Even within such zones, trading has been sparse. See del Calvo y Gonzalez, supra note 14, at 401 n.147.

58. If the polluter wanted more permits, it would have to buy from sellers located near enough to offset its increases. The EPA's "emission offset" policy, see supra note 21, effectively creates a market with a ceiling at the current level of pollution in the immediate vicinity of the buyer. See del Calvo $y$ Gonzalez, supra note 14 , at $385,399-402$.

59. See R. STEWART \& J. KRIER, supra note 8, at 590-92 (discussing plan to prevent localized concentrations in water pollutior: market); Note, supra note 26 , at $809-12$. Of course, setting exchange rates and predicting pollution flows in a river, though far from simple, see UNCERTAIN SEARCH, supra note 12 , at $16-66,81-100$, is much simpler than making the same calculations with respect to the 
very uneven. The seller's decreases would far exceed the buyer's increases. Therefore, the control cost to the seller would be great, and the price of a permit would again be very high. ${ }^{60}$ Furthermore, the costs of administering such a market would be high. To set an exchange rate adequate to prevent hot spots, a complicated model of prevailing winds and topography would be necessary.

In conclusion, modifications of the market could conceivably prevent or diminish the severity of hot spots, but would result in high administrative costs and a chill on trading.

\section{Compensating the Hot-Spot Victim}

A preferable solution would be to provide sufficient compensation to the victims of localized concentrations. ${ }^{61}$ Liability for damages could be established against either the polluters (through a reform of tort doctrine) ${ }^{62}$ or the government (through takings analysis). Like many problems involving governmental authorization of harmful activity, the hot spot can be analyzed as either a nuisance or a taking. ${ }^{63}$

The law of takings is preferable, for the government is a more appropriate source of compensation than the individual polluter. The polluter should not bear the full brunt of compensating victims, for it is not the

\section{atmosphere.}

60. This is not to say that trades would not occur at all, but that many potential trades would be prevented by the price (and potential efficiency gains would be lost).

61. This Note focuses on the victims who live in the area of high pollution concentration. An economist might argue that we should compensate any persons who are injured by the operation of the market, including the landowner whose property value declines because a nearby plant trades away its emissions and closes down, forcing its employees (potential lessees and customers) to move out of town. Causation becomes somewhat tenuous, however, when injuries are caused by multiple economic forces. The same plant might have closed whether Congress had adopted a market or not.

Admittedly, secondary economic effects will also raise or lower the value of hot-spot property, but the presence of high concentrations of pollution indicates that the market itself is causing an injury that would not have existed legally under prescriptive regulation. In the interest of clarity and of limiting the number of claims, the compensation procedures advocated in the Note are limited to hotspot victims.

Finally, as a legal (rather than economic) matter, focusing on harms caused by pollution remedies the very injuries that the NAAQS were designed to prevent.

62. The legislatures or the courts could reform tort doctrine by (1) altering the standards of liability, for example, adopting a strict liability standard and abolishing or reformulating the nuisance balancing test, (2) removing impediments to standing for a class action, and (3) lowering proof requirements by making all polluters in a given zone jointly liable for harms caused by pollution where the exact source is unclear. Cf. Sindell v. Abbott Laboratories, 85 Cal. App. 3d 1, 149 Cal. Rptr. 138 (1978) (sharing of damages under theory of enterprise liability in drug case); Summers v. Tice, 33 Cal. 2d 80, 86, 199 P.2d 1, 4 (1948) (sharing of damages between equally negligent co-defendants where it is impossible to prove which one caused plaintiff's injury); Comment, State Air Pollution Control Legislation, supra note 49, at 720-21; Comment, The Environmental Lawsuit, supra note 49, at $1086-1123$.

63. Cf. PruneYard Shopping Center v. Robins, 447 U.S. 74 (1980) (authorized trespass analyzed as taking); Kaiser Aetna v. United States, 444 U.S. 164 (1979) (same); Griggs v. Allegheny County, 369 U.S. 84 (1962) (authorized private nuisance analyzed as taking); Virginians for Dulles v. Volpe, 541 F.2d 442 (4th Cir. 1976) (interference by flights analyzed as nuisance). 
sole beneficiary of the hot spot. ${ }^{64}$ The public at large benefits from less costly pollution control translated into lower consumer prices ${ }^{65}$ and from improved air. In particular, landowners benefit if they live next to a plant that has sold its emission permits. ${ }^{8 B}$ Polluters that have reaped surplus revenues by selling emission rights ${ }^{67}$ also profit from the creation of the hot spot. Requiring the government to pay damages insures that these other beneficiaries contribute through taxes toward the compensation of the victim.

Compensation by the government would simplify hot-spot litigation. First, such compensation avoids the difficulty of proving which emitters have contributed to a hot spot. Furthermore, a court need not determine whether sellers of permits have proximately caused an injury. The presence of only one defendant also avoids the multiplicity of defendants and claims found in the typical complex environmental lawsuit. Finally, payment by the government prevents the undercompensation that would occur if a company holding a large number of permits became insolvent and therefore unable to pay tort claims. ${ }^{68}$

From the standpoint of fair contribution, administrative simplicity, and certainty, compensation by the government is preferable to payments by individual polluters. ${ }^{\text {g }}$

\section{A. Current Takings Doctrine}

A more difficult question is whether current legal principles require payment by the government. A logical extension of current takings doctrine supports the view that implementation of the market and creation of hot spots would represent a taking of property requiring just compensa-

64. Cr. Griggs v. Allegheny County, 369 U.S. 84, 94 (1962) (Black, J., dissenting) (beneficiaries of air travel should contribute to purchase of local easements), discussed infra note 79.

65. See supra note 33 .

66. But cf. supra note 61 (landowners near seller may suffer other economic harms).

67. A firm will achieve revenues for every permit sold at a price higher than the marginal cost of abating that amount of pollution. If the firm initially received the permit free of charge or if the resale price is higher than the purchase price, then the firm will have a profit.

68. Note, Mass Tort Claims and the Corporate Tortfeasor: Bankruptcy Reorganization and Legislative Compensation versus the Common-Law Tort System, 61 TEX. L. REV. 1297, 1300-01 (1983) (largest asbestos manufacturer filing bankruptcy petition to stay multiple tort actions for asbestosis). This danger seems especially great, since many firms in heavy industries (whose plants would likely have the highest emission levels under a market system) suffer financial difficulties.

69. On the other hand, societal efficiency would be somewhat impaired, since polluters would not internalize the costs of their externalities, and, therefore, would not estimate the potential costs of future lawsuits when determining how many permits to buy.

Yet, the efficiency losses would not be as great as this argument suggests, for information costs (particularly with respect to estimating lawsuits) would undermine the polluter's ability to plan. In addition, present liability rules greatly weaken the ability of plaintiffs to force polluters to internalize their costs. 
tion. ${ }^{30}$ The government takes property when it transfers the right to "use or burden property in a particular way . . from the original owner to another person." In In particular, a taking occurs when the government grants an easement over one person's property to third parties. ${ }^{72}$ In the present case, the government program would create an air easement over the hot spot victim's land. In Griggs v. Allegheny County, ${ }^{\mathbf{7 3}}$ the Supreme Court held that a county had taken an air easement over plaintiff's property by creating an airplane glide path through his superadjacent airspace. Similarly, in the case of a hot spot, the landowner would lose control of an easement through his superadjacent air. The government would transfer control of that easement to a limited market that would allocate pollution without regard to the landowner's interest.

Current case law may not recognize the hot spot as a taking, because pollution may not be a sufficient invasion of plaintiff's airspace. The Tenth Gircuit held, in Batten v. United States, ${ }^{74}$ that localized smoke from an airport was not a sufficient invasion of property to constitute a taking. However, the court expressly distinguished Richards v. Washington Terminal, ${ }^{75}$ in which the Supreme Court held that a taking existed because plaintiff suffered a greater burden than other citizens and because the defendant channeled smoke and fumes across plaintiff's property. The hot-spot victim likewise would suffer an abnormal burden, and the market would represent a federal scheme allocating emission rights to particular sources, thereby channeling society's pollutants through specified easements to reach a general pool of ambient air. ${ }^{78}$

It is true, of course, that private firms rather than government officials would determine the location of hot spots. The Supreme Court, however, recently held that a taking exists where market parties (acting pursuant to government authorization) determine the location of easements. ${ }^{77}$ Furthermore, the private trades would serve a particular governmental function:

70. U.S. CONST. amend. V ("nor shall private property be taken for public use, without just compensation").

71. South Terminal Corp. v. EPA, 504 F.2d 646, 679 (1st Cir. 1974).

72. See Loretto v. Teleprompter Manhattan GATV Corp., 458 U.S. 419, 433-38 (1982); Kaiser Aetna v. United States, 444 U.S. 164, 180 (1979).

73. 369 U.S. 84 (1982).

74. 306 F.2d 580, 583-85 (10th Cir. 1962).

75. 233 U.S. 546 (1914); see Batten v. United States, 306 F.2d at 584.

76. In recent years, a number of state courts have held that pollution entering plaintiff's property represents a sufficient "physical invasion" to create a trespass. See, e.g., Renken v. Harvey Aluminum, 226 F. Supp. 169 (D. Or. 1963); Fairview Farms v. Reynolds Metals, 176 F. Supp. 178 (D. Or. 1959); Borland v. Sanders Lead, 369 So. 2d 523 (Ala. 1979); Roberts v. Permanente Corp., 188 Cal. App. 2d 526, 10 Cal. Rptr. 519 (1961); Martin v. Reynolds Metals, 221 Or. 86, 342 P.2d 790 (1959), cert. denied, 362 U.S. 918 (1960). The same logic would support viewing pollution as an invasion for the purposes of takings law.

77. See Loretto v. Teleprompter Manhattan CATV Corp., 458 U.S. 419 (1982) (cable television company determined location of cable easement). 
the allocation of pollution controls at lowest cost. The government would still find itself closely associated with the allocation process. The market would operate in the context of a federal scheme that set overall levels, distributed permits, established rules for trading, monitored emissions, and perhaps even encouraged trading. ${ }^{78}$ Such extensive governmental participation indicates that the hot spot is not an ordinary nuisance, but is rather the authorized result of a comprehensive program. ${ }^{70}$

\section{B. Compensation Under Current Doctrine}

The hot spot is a taking for which compensation should be paid. Under current doctrine, not every taking of property requires monetary compensation. ${ }^{80}$ Although the Supreme Court has yet to develop a clear formula for determining when compensation is due, ${ }^{81}$ the Court has identified a number of relevant factors: the economic impact of the governmental action, the extent to which the action has interfered with reasonable investment-backed expectations, and the character of the action. ${ }^{\mathbf{} 2}$

The last factor is particularly important. The Court has more readily found a compensable taking when the governmental action "will result in an actual physical invasion" of private property. ${ }^{83}$ The Court has adopted this position in an air easement case ${ }^{84}$ and in a case in which the government granted an easement to third parties. ${ }^{85}$ Such a doctrine reflects the common judicial view that an owner suffers "a special kind of injury" when his property is invaded. ${ }^{86}$ As discussed above, the focused concentra-

78. See supra p. 1028 (government may actively promote trades to "grease the wheels" of a pollution market).

79. Similarly, in Griggs v. Allegheny County, 369 U.S. 84, 89 (1962), the county was held liable for damages actually caused by private airlines following an authorized glide path. To be sure, Griggs represents a stronger case of governmental action, since the county actually chose the location of its runways. Justices Black and Frankfurter, however, argued in dissent that the federal government should be held liable for setting up a comprehensive program that authorized counties to build airports and take easements. Id. at 94 (Black, J., joined by Frankfurter, J., dissenting). They stressed the point that because the whole nation benefited from the federal scheme, the individual county should not have to bear an unfair proportion of the costs of easements. Id. The logic of sharing proportional costs is likewise strong where the federal scheme affects the allocation of a public good: clean air.

80. See PruneYard Shopping Center v. Robins, 447 U.S. 74, 82 (1980); Armstrong v. United States, 364 U.S. 40, 48 (1960).

81. See, e.g., Loretto v. Teleprompter Manhattan CATV Corp., 458 U.S. 419, 426 (1982); Kaiser Aetna v. United States, 444 U.S. 164, 175 (1979); Penn Cent. Transp. Co. v. New York, 438 U.S. 104, 124 (1978).

82. See, e.g., Loretto, 458 U.S. at 426; PruneYard, 447 U.S. at 83.

83. Loretto, 458 U.S. at 433 (quoting Kaiser Aetna, 444 U.S. at 180) (emphasis omitted).

84. United States v. Causby, 328 U.S. 256, 265-66 (1946). The Causby Court distinguished Richards v. Washington Terminal, 233 U.S. 546 (1914), referring to that portion of Richards in which compensation was denied for damages due to incidental smoke. 328 U.S. at 262. The hot spot, however, closely resembles the invasion by channeled pollutants, which was held to be compensable in Richards.

85. Kaiser Aetna v. United States, 444 U.S. 164, 180 (1979).

86. Loretto v. Teleprompter Manhattan CATV Corp., 458 U.S. 419, 436 (1982). 
tion of pollutants in a hot spot represents a sufficient physical intrusion to view it as an invasion of the landowner's property. ${ }^{87}$

In addition, the hot-spot victim has been injured due to reasonable investment-backed expectations. His investment in property and continued uses $^{88}$ of it have reflected his expectation that the government would not allow pollution to exceed safe levels. The Court, in Kaiser Aetna v. United States, ${ }^{89}$ placed great weight on expectations developed in reliance upon a governmental promise. The strong commitment in the Clean Air Act to uniform protection of health ${ }^{90}$ would engender clear expectations of minimal air quality.

Above all, the Supreme Court has noted that the basic issue underlying the compensation clause is whether the interference "forc[es] some people alone to bear public burdens which, in all fairness and justice, should be borne by the public as a whole." "91 Given the move from a strictly equitable system to one that singles out a few individuals to suffer for the benefit of the general public, compensation is especially appropriate. ${ }^{92}$ In sum, takings doctrine would require that the government compensate victims of hot spots.

\section{G. Baseline for Compensation}

The NAAQS developed pursuant to the Glean Air Act form an appropriate baseline against which to measure a taking. They establish a national, uniform status quo. Based on pollutants' effects on persons and land, NAAQS effectively set the outer limits on one characteristic of real

87. See supra p. 1034.

It could be argued that the concentration of pollutants is a "permanent" invasion, giving rise to a taking per se. See Loretto, 458 U.S. at 426-35. By permanent, the Loretto Court meant that the intrusion is continuous, not that it is of infinite duration. Thus, the installation of a television cable was deemed permanent. Id. at 437-39.

A hot spot might be considered permanent because it is a continuous concentration. On the other hand, a court might hold that the hot spot more closely resembled the non-permanent easement in Kaiser Aetna v. United States, 444 U.S. 164 (1979), because each invader (each particle of pollution) moved through the property. See Loretto, 458 U.S. at 433 (discussing Kaiser Aetna). In any event, even if a hot spot were not considered a permanent intrusion, it would still be subject to the strict standards that apply to any actual invasion.

88. High levels of pollution will interfere directly with the landowner's ability to maintain current uses of his land, thus distinguishing this case from Penn Cent. Transp. Co. v. New York, 438 U.S. 104, 136 (1978), where a challenged regulation prevented only anticipated uses (unsupported by any actual investment). Also, in Penn Central, the regulation caused no physical invasion of plaintiff's property. Id. at 135 .

89. 444 U.S. 164,179 (1979).

90. See supra p. 1023.

91. PruneYard Shopping Center v. Robins, 447 U.S. 74, 83 (1980) (quoting Armstrong v. United States, 364 U.S. 40, 49 (1960)).

92. This "equality" component of the takings clause distinguishes the hot-spot problem from the situation in which the government merely relaxes NAAQS. In the latter case, expectations are dashed, but the change does not force a few individuals to bear special burdens to benefit the rest of society. 
property in the United States. Moreover, they set a standard of protection from physical invasion. Any violation of that standard implicates the values seen by the courts as most clearly protected by the takings clause: security in the status quo and protection against government-authorized invasions of land.

The Clean Air Act is unique in setting national standards that regulate physical invasions and that are based on the impact of pollutants on persons and land. Therefore, the institution of a pollution market creating hot spots would be distinguishable from most other changes in governmental programs (such as zoning changes or elimination of entitlements). Because the courts have drawn a line between actual invasions of property and mere economic pressures, the hot spot would involve a compensable taking of property whereas most other governmental actions would not. ${ }^{93}$

\section{Statutory Liability}

As the preceding sections show, hot spot victims would have a constitutional cause of action against the government entity that established the market. Congress, nevertheless, should create an explicit cause of action to be heard in an administrative tribunal. ${ }^{94}$ Such a statute could eliminate some of the pitfalls that victims might face if they had to rely on the courts to recognize an unconstitutional taking. For example, the statute would clarify the victim's right to compensation; ${ }^{95}$ otherwise some courts

93. The hot spot is also distinguishable from a modification of NAAQS, because the hot spot involves a particularized interference. Although raising NAAQS would increase the potential invasions of airspace, the burden would be shared by all citizens. Since takings doctrine focuses on individual burdens, a generalized interference is not a taking.

Even if pollution levels did not rise in every region to the new ceiling permitted by the amended NAAQS, one region would not automatically carry a burden for the rest of society. The market hot spot would ensure cleaner air in other regions.

Finally, the mere alteration of NAAQS would not undermine the basic purpose of the Clean Air Act: to maintain breathable air in all regions. In contrast, the creation of a market theoretically permitting all the pollutants in an AQCR to be focused in one locality would abandon both the Act's equitable purpose and the notion of maintaining breathable air. Some regions could be unsafe, unless the total number of pollutants in the AQCR were set so low that a complete concentration (resulting from the ownership of all permits by one polluter) would not exceed the levels considered safe by the EPA.

In sum, the market hot spot is a more individualized burden and, therefore, violates the takings clause whereas a mere increase in NAAQS does not.

94. Admittedly, such a system might not be perfectly efficient, for example, if the landowner received greater compensation than he would have accepted through negotiation with the polluter. $C$. Calabresi \& Melamed, Property Rules, Liability Rules, and Inalienability: One View of the Cathedral, 85 HARV. L. REV. 1089, 1118 (1972) (efficiency achieved through bargaining between polluter and "pollutee"). It may be justified, however, to trade off some efficiency in order to provide a more certain remedy and to ensure that all the beneficiaries of the market contribute to compensation payments.

95. Congress would base its statute on the victim's constitutional right to compensation. The conclusions of takings analysis are binding on the legislative and executive branches as well as the courts. Indeed, the legislature and executive agencies often draft statutes or regulations concerning compensation procedures. See, e.g., Declaration of Taking Act, 40 U.S.C. $\$ \S 258 a-c$ (1976) (procedures for 
might be less than eager to recognize this justification for an award.

As a policy matter, providing an explicit compensation scheme might also expedite the creation of the market. Legislators, suspicious of the market concept, would be less worried and less opposed if they felt that victims were certain to receive compensation.

Finally, statutory treatment permits Congress to tailor jurisdictional requirements and standards of liability carefully. Assuming that federal legislation or regulation authorized the market scheme, the compensation statute would require the federal government to compensate landowners and residents ${ }^{96}$ for damages resulting from a hot spot sanctioned by that market. The statute would create a special administrative hearing board ${ }^{\text {97 }}$ and give it jurisdiction to hear claims and assess damages. As a first hurdle, a plaintiff would have to show that pollution levels in his superadjacent airspace after a trade or after the initial distribution of permits were higher than would have been permissible under primary NAAQS. ${ }^{98}$

transfer of land amount to a taking); Federal Highway Administration, Acquisition Function, 23 C.F.R. $\S \S 712.101-712.805$ (1983) (taking of lands for highway projects). Thus, the same theory that informs judicial determinations of compensation could likewise guide the legislature in creating a statutory claim for compensation.

96. Residents (such as lessees) as well as landowners are protected by the takings clause. See, e.g., United States v. Right to Use and Occupy 3.38 Acres of Land, 484 F.2d 1140 (4th Cir. 1973) (lessee's right to compensation for loss of leasehold); Pekofslry v. State, 15 Misc. 2d 358, 180 N.Y.S.2d 930 (Ct. Cl. 1958) (same).

Arguably, other persons, such as employees who spend considerable time in a region, also deserve compensation. They may be as bound to a region by economic necessity as residents are bound by investment. The compensation statute could, in theory, be modified to include such persons. The administrative costs of separating worthy beneficiaries from unworthy ones, however, would be great. Determinations of the relevant locale for measuring concentrations would require complicated factfinding and subtle distinctions, compounding the difficulty of proving causation of injuries.

Using property ownership and residency as criteria might also allow some unworthy parties to bring actions. Those criteria, however, would at least provide a clear definition of the locale for measuring a concentration and some assurance that the plaintiffs had suffered hot-spot related injuries. Even absentee property owners would suffer from diminution in real estate value.

Furthermore, focusing on the injuries of property owners and residents vindicates the central concern of takings doctrine: protecting the individual against invasions of property.

97. Creating a special hearing board to hear claims would have a number of advantages over using the federal courts. First, the board could develop expertise in the field of air pollution injuries. Second, the courts, already confronted with heavy caseloads, would not have the additional burden of hearing pollution market compensation claims.

Non-judicial officers often make the first assessment of damages in just compensation cases. Sec, e.g., Real Estate Activities of the Corps of Engineeers in Connection with Civil Works Projects, 33 C.F.R. $\S 211.4(\mathrm{~b})(2)$ (1983) (Corps making initial assessment of just compensation and depositing bond with court); FED. R. CIV. P. $71 \mathrm{~A}(\mathrm{~h})$ (court-appointed commissioners determining compensation). Moreover, rule $71 \mathrm{~A}$ recognizes the power of Congress to constitute a tribunal for the determination of just compensation issues.

98. Choosing primary rather than secondary NAAQS as the baseline for liability ensures that injuries to health (as well as welfare) are related to the violation of former national standards. Furthermore, the choice avoids the difficulty of deciding what would have been a "reasonable time" for compliance with secondary NAAQS. See supra note 8.

Even if the original distribution merely ratified former violations of the NAAQS program, a taking would theoretically occur because now those excesses would be authorized by law. There might be no damage to property, however, since pollution levels had not changed and driven property values down. 
Damages would be determined by the difference between the market value of plaintiff's land before and after the trade, plus any health-related damages ${ }^{89}$ incurred by plaintiff as a result of the high pollution concentrations. ${ }^{100}$ (Of course, it may be difficult for plaintiff to quantify or monetize health damages, or to prove that they were caused by pollution. ${ }^{101}$ )

The statute would also assign burdens of proof. The diminution in property value after a trade would create a presumption that the loss was due to the development of the hot spot. The government, however, could rebut the presumption by showing that part (or all) of the loss was attributable to other causes.

On the other hand, a stable or rising property value would create a presumption that the hot spot had caused no injury. The burden would then be on the plaintiff to show that his property value was not as high as it would have been but for the existence of the hot spot. ${ }^{102}$

The federal government would be liable for any damages the board assessed. The governmental defendant could, of course, adopt a policy that ensured "contribution" from polluters in the relevant market region. For example, if the government started the market by assigning property rights on the basis of former SIP requirements, ${ }^{103}$ it might demand contribution for future harms by assessing a one-time property tax on emission rights and thereby creating a pool from which to pay plaintiffs. If the

99. Courts often require the government to pay for damages incidental to a taking of property. See United States v. 9.20 Acres of Land, 638 F.2d 1123, 1126-27 (8th Cir. 1981) (injury to other land compensable); United States v. 339.77 Acres of Land, 240 F. Supp. 545, 549 (W.D. Ark. 1965) (injury to equipment compensable).

Furthermore, if the government had compensated the landowners ex ante for the taking of the easement, anticipated personal injuries would have constituted an element affecting the value of property. See United States ex rel. TVA v. Two Strips of Land in Trigg County, 249 F. Supp. 747 (W.D. Ky. 1966) (court could consider expected injuries to health). Awarding damages for personal injuries would theoretically correct for the time lag between an ex ante and ex post evaluation. To include health damages is not "double-counting," for the current market value of the property reflects only future injuries to health, not injuries already suffered by the plaintiff.

100. In order to prevent multiple frivolous claims and limit process costs, the board would require that a plaintiff prove substantial damages, not just a slight diminution of the value of his property.

101. First, the plaintiff may have difficulty in proving the extent and monetary value of injuries to health. However, it should at least be possible to prove the expenses incurred in treating a medical disability, and the tribunal could retain jurisdiction over a case in order to award payment for expenses incurred after the initial hearing. Furthermore, though valuation of pain and suffering would be somewhat speculative, courts have traditionally assessed such damages.

The plaintiff may also have difficulty in proving that pollution rather than other influences (such as smoking) caused his injury. See supra note 52. Lawyers and commentators have attempted to develop techniques for making this proof. See Note, supra note 52, at 857 (use of statistical probabilities to create presumption that cancer caused by pollution); $c f$. Industrial Union v. American Petroleum Inst., 448 U.S. 607, 636 n.41 (1980) (offer of statistical evidence during OSHA rulemaking on benzene standard); Krier, Environmental Litigation and the Burden of Proof, in LAW AND THE ENVIRONMENT 105, 107, 117-20 (M. Baldwin \& J. Page eds. 1970) (suggesting that burden of proof be lowered). In general, however, the courts have yet to adopt these changes.

102. In either case, the plaintiff would have the burden of proving health-related damages.

103. The "emission offset" program, for example, starts from a baseline determined by SIPs. See supra note 21 . 
market commenced with a general auction, ${ }^{104}$ the government might similarly pay damages out of the proceeds from the auction. Neither approach would harm the internal efficiency of the pollution rights market. The relative costs of control technology would still induce polluters to trade emissions and reach an optimal mix. Moreover, this tax would be "fair" in that other beneficiaries of the market would still contribute, since the government would pay only part of the damages out of the pollution tax pool, paying the rest out of general tax revenues.

Naturally, if the government wanted to create incentives to avoid hot spots, it might tax the polluters who bought emission permits more heavily than other members of the market. This could be achieved by putting a tax on the emissions transfer or by taxing emission rights every year. Such a decision, however, would sacrifice the internal efficiency of the market for the sake of more consistent air quality.

\section{Conclusion}

The creation of a market in pollution rights would pose a significant risk of localized injuries that the government could mitigate by providing compensation to individual victims. Takings doctrine provides a constitutional basis for compensation, and Congress should recognize the obligation by creating an explicit statutory cause of action in an administrative tribunal.

104. See supra note 23 . 